\title{
Theatrical Milieu: Investigating Drama and Theatre in tandem with Socio-Political
}

\section{Landscape of Pakistan}

* Fareeha Zaheer (Corresponding Author)

\begin{abstract}
This study is an attempt to trace the impacts of socio-political conditions in the formation and evolution of drama and theatre traditions in Pakistan. It provides the genesis of theatre and drama in Pakistan intertwining it with the past and present situations of this genre of literature. It also ventures at the inert position of drama and theatre in English in Pakistan. Qualitative textual analysis is conducted to analyze and highlight the major available critical acumen in the genre of Pakistani drama and theatre. The methodology adopted is interpretive of the theatrical performances by major theatre groups, and the contributions of key playwrights in cementing the foundation of drama and theatre traditions. The major findings are related to the socio-political situations prevalent since the inception of Pakistan and their significance in shaping both dramas in writing and drama in performance. It also examines the role of pioneer theatrical groups and their projects that carved a niche in the theatrical landscape of Pakistan. As compared to fiction theatre and drama remained sporadic and lackluster affair in Pakistan, it is vital to have a deeper understanding and clarity of the socio-political issues that shaped resistance \& political theatres and later commercial theatre groups.

Keywords: Theatre and Drama, Socio-Political Landscape of Pakistan, Theatre and Drama in English.
\end{abstract}

\section{Introduction}

Drama \&Theatre in Pakistan are rooted in the colonial past and the Colonial experience is not only a political reality but also a psychological invasion. The invasion which started from the occupation of natural resources turned into a complex social phenomenon when two unknown cultures interacted closely. Postcolonial Literature emerged as a literary strategy of representation of the local culture that is helpful in the nation-building process. Postcolonial drama in form of texts and performances lead to defy and rectify the damaging effects of colonial experiences simultaneously representing and reviving national cultures and histories, which include indigenous cultural practices through discourse. Hence a shift from object position defined by Eurocentric colonial discourse to a subject position with an agency of writing back to the empire.

Postcolonial theatre according to Naseer Dasht Peyam offered a literary form that shaped the languages and cultural practices of "collective memory and identity." $(2009$, p.6) Theatre plays a crucial role in shaping the independent identity of emerging nations and creating cultural sensibility. Since theatre as compared to written drama offers a variety of creative scope as it attempts various prospects like multi-layered narration through diverse stage techniques William Worthen (2000) argues that "contrary to other literary forms drama is written to be performed for the audiences, hence confronting them publicly." (p.3)

\section{Literature Review}

\section{A B rief History of Drama and Theatre in Pakistan}

The rise of drama and theatre in Pakistan is majorly indebted to Urdu Theatre traditions. Urdu theatre started flourishing in Subcontinent in the late $19^{\text {th }}$ century when Sanskrit theatre was facing downfall as mentioned by Mohammad Aslam Qureshi (1989). The first Urdu Play in theatre was Indrasabha in 1855 by Agha Hassan Amant who drew inspiration from Wajid Ali Shah, a Kathak dancer who wrote about theatrical and practical components of performing arts. Urdu became the language of the northern region of the Subcontinent and an important medium for commercial theatre introduced by Parsis. Initially, Urdu theatre adopted local traditions of Rhas i-e plays based on old epics by combining dance and music. Jameel Jalibi (1989) espouses that it also drew inspiration from commercial dance i-e Mujra, alongside local slapstick and improvisation comedy known as Bhand. Rehmani (1987) states that not only these elements influenced Parsi theatre, but also Shakespearean

* National University of Modern Languages, Islamabad Email: fareeha.zaheer@uettaxila.edu.pk 
play adaptations were performed in collages by English troupes visiting Subcontinent inspired Parsi Theatre. In Parsi theatres, Urdu adaptations of Shakespeare plays written by Agha Hashar Kashmiri (1879- 1935) were performed. These theaters also learned and utilized techniques of lighting, costumes, and direction from British troupes.

After independence in 1947 Lahore became the center of cultural activities and even today it is a significant cultural hub of Punjab, Pakistan. Folk theatre adopted folklore and musical stories based on folk rhythms and tunes in form of Nautanki and Tamasha ${ }^{1}$ in rural areas of Punjab. Largely Arts and literature couldn't receive proper patronage and ownership by any government to date as the social fabric of Pakistan is also divided in class stratification where art and literature are considered a privilege and associated with an upper class or upper-middle class only. This is the reason serious theatre either in Urdu or in English had been limited to educational institutions like Government College University, Lahore, and Arts Councils. These theatrical productions in the 1960s and 1970s were labeled as elitist because they drew impetus from a Western culture with very few scripts by indigenous playwrights. Simultaneously when the question of bringing the audience arises, these dramas failed to capture the lower or middle classes. However, their contribution in drama \& theatre cannot be subsided as they kept this form of art somehow alive. Another kind of theatre that flourished parallel to the elitist theatre is Punjabi or Urdu commercial theatre that included Juggat ${ }^{2}$ but with time the quality of content degenerated into crude humor and vulgar dances, but the interesting fact is that it attracted masses which speaks volumes about the plight of art and literature in Pakistan. Currently, the National Academy of Performing Arts (NAPA) founded in 2005, Ajoka Theatre, Alhamrha Arts Council, and Rafi Peer Theatre are renowned names in producing drama and theatre in both Urdu and English languages.

Since its inception in 1947, Pakistan and its people have faced evitable and inevitable woes orchestrated by socio-political instability and wars. The socio-political elite has ruled the country and the status quo of feudal, bureaucracy, aristocracy, and business elites have maintained their hegemony in socio-political fronts. According to Fareeda Shaheed "For most of Pakistan's history, the real power contestation has been between the military-dominated center and the sub-national political elite" (2018, p.4). The first military coup happened just after eleven years of Pakistan's independence. And in 1971 after Bangladesh came into being the first democratic government was established by Zulfiqar Ali Bhutto as a result of his pro-poor slogans and tried to lessen the hold of the elite in politics but ultimately deviated from his non-conformist ideology. Ahmar is of the view "his mode of governance was criticized as authoritarian because he expressed the least tolerance vis-à-vis his political opponents. Curbs on the press, opposition political parties and other coercive measures used by him to silence opposition made a mockery of democracy during his rule" $(2015, \mathrm{p}$.1). Once again the democratic government was overturned as a result of the $2^{\text {nd }}$ Martial Law in 1977 by General Zia ulHaq. Drama and Theatre play a vital role in depicting the socio-political conditions of any society. Pakistan remained under a dictatorship regime for almost thirty-five years. Arts and Literature were under severe scrutiny in the era of General Zia-ul-Haq. Poets like Faiz Ahmad Faiz, Habib Jalib, and Ahmad Fraz were banned on national platforms. Ajoka Theatre emerged in these turbulent times.

Asma Mundrawala in her doctoral dissertation Shifting Terrains: The Depoliticisation of Political Theatre in Pakistan (2009) discusses that Ajoka and Tehrik e Niswan in their inception years adopted the role of political theatre. Their genesis is deeply rooted in the political ideology of resistance against Marshal Law and laws against women. Both theatre groups follow Brechtian tradition and used theatre as a medium to activate the general public for social justice. She states that after the end of the military regime these theatre groups got acceptance by the democratic forces of state and society, hence shifting their focus from what Hajra Mumtaz states as a shift from "politics to social commentary, gradually being incorporated into the dominant culture" (2009, p.93). Mundrawala states that with the advent of neo-liberalization in the 1990s, theatre in Pakistan transformed into a commodity as a result of NGO funding and hence promoting their agenda. Mundrawala declares it a shift from "activism to paid activism the commoditization of theatre which had served as a tool for socio-political critique and the depoliticization of public life brought about by development agendas" (2009, p.6).

\footnotetext{
${ }^{1}$ Both words are used in Urdu for theatrical performances

${ }^{2}$ A prompt and improvised comedy
} 
Fawzia Afzal Khan (2005) highlights the historical and political contexts in which theatre emerged as a cultural form. Khan foregrounds three major theatre groups Ajoka, Tehrik e Niswan (Literal meaning is Women's Movement), and Punjab Lok Rehash. She argues that theatre can serve as a means of "enlightenment, education and action" (2005, p.72). Two of these groups i-e Ajoka and Tehrik-e Niswan appeared in the 1980s to counter the radical Islamization of Zia ul Haque's regime, as resistance and protest and to create awareness and education among the masses. She further expresses that these theatre groups have contributed to the landscape of theatre \& drama in Pakistan yet these alternative theatre groups need to adopt western concepts of deconstruction, poststructuralism, and feminism rather than merely focusing on a relentless feminist approach.

\section{Methodology}

Qualitative textual analysis is the approach and method for analysis in this study. Textual analysis is a tool to decode texts and content hence providing an interpretation and criticism of the texts. It is a vital strategy in exploring behaviors, attitudes, and socio-political conditions in which a particular text is produced. "Textual Analysis as a Research Method." Belsey states that "textual analysis is indispensable to research in cultural criticism" (Belsey,2005, p.157). As textual analysis helps in understanding the content, the research paradigm is exploratory and interpretative.

\section{Discussion and Findings}

\section{Religious Oppression and Voices of Protest}

From the first military coup in 1958 by General Ayub Khan to the separation of East Pakistan in 1971 which is now Bangladesh, up to Zia's regime, and then to the contemporary crisis of religious and ethnic intolerance still jolting so-called democratic state raising concerns among civil society and masses about socio-political stability. The Pakistani nation has been unable to surmount sociopolitical and economic challenges for several reasons which include the religious and ethnic diversity of citizens. Polarization at both religious and political fronts continues to date as blasphemy laws in Pakistan's constitution being misinterpreted and misused by the general public, as the recent example is the blasphemy case verdict of Asia Bibi. A Christian woman who is recently acquitted by the Supreme Court of Pakistan while she was falsely charged for religious blasphemy. But the religious fanatic group of Tehreek e Labaik (TLP) Pakistan not only held a protest rather locked down the capital which later ended in a truce between the government and TLP leadership. It is not only that religious minorities are suffering from such extremist mindsets, but people like Salman Taseer ${ }^{3}$ and Mashaal Khan ${ }^{4}$ faced death because of religious bigotry, though the culprits involved in both cases were served justice. Fakia Tahir (2019) investigates the reasons for religious extremism and elaborates two approaches i-e religious pluralism or religious exclusivism. Tahir suggests that Pakistani society generally lacks patience and tolerance for differences of opinion.

Having said that it is vital to assert that largely, Pakistani society is still religiously political and politically religious where dialogue is always shadowed by fear and threat and hence creating obstacles for the growth of a democratic and progressive society. Lisa Curtis (2016) examines the one major reason for religious intolerance in Pakistan is a deviation from the vision of the Founder of Pakistan which was peaceful coexistence of various ethnicity. This polarization is even more evident in the recent past when a movie by Sarmad Sultan Khoost named Zindagi Tamasha ${ }^{5}$ (Circus of Life) is duly approved by Federal and provincial censor boards yet the movie is on hold after a complaint has been launched against the movie for calling its content blasphemous. The movie is internationally acclaimed at Busan Film Festival and it narrates the story of a struggling cleric who incites the Islamic fundamentalist element, spewing hatred, fear, and anger in the name of religion. The sorry state of affairs is that Government has sent this movie for review the Council Is lamic Ideology and aga in TLP holds the center stage in this whole episode. It indicates that religious ly motivated political element is penetrated deep in Pakistani society which results in oppressing freedom of speech. Saramd Sultan Khoosat who is director and co-producer of this film has written an open letter on Twitter to the Prime Minister of Pakistan in which he articulates that he is blamed for maligning the image of clerics via this movie, in addition to this he is receiving death threats. He further implores that "the space for

\footnotetext{
${ }^{3}$ Former Governor of Punjab, murdered on $4^{\text {th }}$ January 2011 by his bodyguard for speaking about amendments in Blasphemy laws.

${ }^{4}$ Lynched by a mob in Abdul Wali Khan University, on the accusation of his friend for posting blasphemous content online.

${ }^{5}$ https://www.bbc.com/news/world-asia-51201994
} 
rational and artistic thinking and expression must not be annexed by a few troublemakers for their political ends but I fear this is what will happen if we buckle under this time." (Sarmad, 2020, para.10).

To conclude it is important to mention remarks of the Munir Commission in 1953 that is even much relevant to 21st-century Pakistani society regarding the tension between religion and politics which states that lack of clarity and dysfunctional working of the government has brought Pakistan into a state of confusion where leaders lack concrete strategies and seem clueless about irreconcilable issues since opposing principles are left to their own which can only produce chaos and application of neutralizing agency to them can only produce dead results.. as long as we rely on the hammer when a file is needed and press Islam into the service to solve the situations, it was never intended to solve, frustration and disappointment must dog our step. If political leadership in Pakistan had taken measures in the light of this analysis regarding religious and political dynamics, we would have been living in a very different country.

\section{Analyzing Resistance and Protest, The Role of Political The atre Groups :}

Over the last seven decades largely Pakistan remained an ethnically heterogeneous and religiously fanatic society. Religious fanatic ism gained momentum in Zia's era as a result of his Islamization drive. Religion has been politicized by the individuals to gain dominance over the masses who are already poverty-stricken and deprived of proper education facilities. In the social fabric of Pakistan where political and religious oppression is not the only menace but social oppression in form of exploitation of basic human rights based on socio-economic classes and gender is quite a norm. Unfortunately, access to basic human rights like education, housing, and justice are considered privileges of certain socio-economic classes thus it creates a huge devoid between have and have nots, empowered and disempowered. The ineptitude of the state to provide justice across the board has been a critical factor in tandem with the failure in creating awareness about existing laws for the citizen has capacitated traditional structures like the Jirga system prevalent in Sindh, Southern Punjab $\&$ tribal belt, to administer parallel state structures.

While I have already explained how religious and political oppression has shaped over the years, Pakistani women that are almost 50 percent of the total population have struggled and to date struggling against social and religious oppression. The provenience of this oppression has its roots in Zia-ul Haq's regime that not only curbed democratic traditions but also known for anti-women stance on every front. Laws were introduced to decrease women's public visibility and to confine them in veil and four walls. The infamous Hadood Ordinances ${ }^{6}$ in 1979 replaced the secular legal system prevalent at that time hence introduc ing Is lamic punishments of stoning, whipping, and amputation in cases of consensual sex, rape, and adultery. These laws were ill drafted and disseminated in haste primarily to establish an 'Islamic' state which was largely politically motivated hence turned women into a disenfranchised group. The notoriety and flaws of this law placed women in a discriminated and disempowered position since the burden of proof in case of rape lies with the victims mostly women have to provide sufficient evidence to convict the accused. Adding to this in patriarchal social setup many husbands made rampant misuse of this law by accusing their wives and launching complaints. What makes this law more problematic that it undermines the basic rule of law that is equality since the law variegates depending upon gender and religious notions of the accused, the victim, and those providing evidence like if the accused was Muslim and witnesses had evidence but were nonMuslims, maximum punishments could not be granted.

Apart from the legal perspective, Zia's regime brought gender segregation in social and public gatherings, prohibiting male-female cultural performances in colleges and universities. Women were allowed to partic ipate in women-only national games. Women working on media were forced to cover their heads. Hence it resulted in such a repressive social environment which promoted the idea that individuals can hold any woman accountable who is infringing the ir sense of Islamic morality. Zia's attempts of marginalization became a catalyst for the organized resistance and protest movements led by female social and human rights activists like Asma Jahangir and Hina Jelani in the 1980s. It also led to the production of feminist literature in the 1980s by Khiswar Naheed and Fehmida Riaz, who are considered pioneering voices and stepping into female sexuality and portraying women's political and social spaces in their writings.

\footnotetext{
${ }^{6}$ Martin Lau, Twenty-Five Years of Hudood Ordinances- A Review, 64 Wash. \& Lee L. Rev. 1291 (2007), https://scholarlycommons.law.wlu.edu/wlulr/vol64/iss $4 / 2$
} 
NGOs and foreign-funded projects for women opened the gateway of Western metropolis and academia. Benazir's two short tenures (1988- 1990 \& 1993- 1996) provided a bit eased environment for women socially and politically. Women were given a 5\% quota, placement of women to high court judges positions and introduction of women police stations were few steps that created a minor dent in overall societal behavior promoted in Zia's era. It was in Musharraf's regime the idea of the moderate image of Islam was established in the wake of $9 / 11$ by promoting the idea of religious tolerance at the national and global level. There was a stark difference in Musharraf's polic ies to his predecessor as he promoted freedom for electronic media, enlightened vision about Islam and Muslims after Islamophobia hit the Western world alongside his socially liberal polic ies included an increased number of women representation in the National Assembly bringing ghettoized women in parliament and introducing Women Protection Act in $2006^{7}$. This bill is a landmark and considered progressive legislative documents since it reformed Hadood Ordinance and the Council of Islamic Ideology played a vital role in bringing drastic changes in line with Islam. According to this Act offenses like rape and fornication are governed by Pakistan Penal Code. Anyone with a false accusation of adultery faces a high risk of punishment if his complaint doesn't result in a conviction. Yet in the patriarchal social set up there is much needed to be done to make the legislative system responsive towards the needs of Pakistani women.

An important aspect while discussing Islamic laws and Islamic social setup, is to mention that Islam provides rights to Muslim women and it is not a religion that deprives women of their basic human rights as propagated by many liberal and secular elements nationally and internationally. There is a complete chapter in the Quran regarding the rights of women with the name of Surah-e Nisa. As Jalal states that Islam accords ample rights to women it is the state and male-dominated society that fails to provide and protect these rights (1991, p.92) The low literacy rate, lack of awareness, and blindfolded following of clergymen who portray Islam as a religion of oppression are the main reasons to strip off women from basic human rights in the name of faith.

Thus in Zia's regime, the socio-political oppression created a nexus with a religious element, perpetuated sanctions on freedom of expression, and marginalized Arts and Literature. This political climate vitalized people from performing arts and Dastak, a theatrical group founded in the early '80s in Karachi by Aslam Azhar and Mansoor Saeed who believed theatre is an effective medium to reach the common man. Asma Mundrawala says "Their subjects were pertinent to the politically charged atmosphere of the time, and bore relevance to their leftist ideology." (2007, p.59) Dastak gathered the attention of many political workers as it performed political street theatre in various areas of Karachi, as its productions were adapted versions of Brecht and Safdar Hashim's plays. Erven (1992) notes that Dastak was the first political theatre in Pakistan that has a wide range of members from factory workers to those who reside in slums, university students, and office workers, hence representing various strata of Pakistani society with varying level of political awareness. Mansoor Saeed in his interview with Ms. Mundrawala told that the rise of MQM (Mutahida Qomi Movement) supported by General Zia ul Haq, disrupt the political popularity of Benazir Bhutto in Sindh, brought the reign of terror in the late '80s and '90s. The terrorized atmosphere of uncertainty and threats to survival brought down the number of audiences alongside various members who moved abroad to pursue their careers and ultimately this theatrical group disbanded in the '90s. Hence a major voice of dissent and protest became silent as a result of political oppression and turbulent social conditions. Presently, the socio-political situation is much different as MQM has lost its political and militant hold in Karachi and as a result cultural activities like Karachi Literary Festival ${ }^{8}$ and International Theatre Festival ${ }^{9}$ by the National Academy of Performing Arts (NAPA) has been regularly organized in this decade.

Drama and theatre that highlight the power dynamics of socio-political realities are termed as political theatre/ plays, alongside having the social commitment and mobilizing collective consciousness. Nagugi (1986) states that Literature and politics are related to each other in such a way that they are reflected in one another and fact act on each other. Artists and literary figures are sensitive towards the problems in society and hence they cannot close their eyes and ears from the prevailing socio-political issues. Drama as an art form provides a retrospective view by a dualism

\footnotetext{
${ }^{7}$ See President Signs Women Protection Bill, FRONTIER STAR (Pak.), Dec. 1, 2006, available at 2006 WLNR 21128068 (noting the passage of the bill).

${ }^{8} \mathrm{https}: / /$ www.karachiliteraturefestival.com/about-us/

${ }^{9} \mathrm{https}: / /$ napa.org.pk/theater-introduction.html\#
} 
between concept and action, between creation and performance, and between fiction and reality. Thus the artistic representation through drama hits the core of the issues and hence creating niches for discourse and debate. In essence, theatre and drama investigate realities, and these realities in return impact literary productions

Ajoka's inception in Lahore and Tehreek e Niswan genesis was the result of a similar ideology that theatre is an institution that inspires much-needed change in society by investigating societal problems and by protesting against socio-political oppression. Both these theatre groups are the pioneer of political theatre in Pakistan. They recognized the need to restore life to the oppressed people of Pakistan hence seeking to create a new vision for revival, progress, and collective consciousness for a better and transformed society. Zakes Mda in a seminar in 1996 says that theatre as means of protest doesn't attempt to appeal to the consciousness of the oppressor rather it addresse s the oppressed directly and mobilizes them to stand against oppression.

Threek e Niswan started its journey by focusing on women's rights and presented plays written by women writers. Plays like Dard k Faslay and Aurat are plays articulating the plight of women in times of oppression, where they have to fight patriarchy, harassment, and the familial pressure of forced marriages. It is important to mention that Tehreek Niswan (tans. movement for women) as the name suggests played a key role in promoting women with the potential of arts and literature. On the other hand, plays performed under the banner of Ajoka stimulated discussion on crucial political issues, which may not be articulated otherwise. It may be regarded as an interventionist against the silences imposed by the government institutions. One such example is The Third Knock, in which tenants in the apartment kill their landlord and that landlord returns from dead while these tenants are celebrating the ir success. The landlord returns thrice during the play as the metaphor of recurring dictatorship in Pakistan. Ajoka became the leading theatrical banner in Pakistan that kept on voicing the unspeakable by embedding its message in a metaphorical way when the government was placing strict censorship policies on the content delivered through art and performances. Ajoka kept on registering its protest through performances against the state dictated oppression and exposes the process of cultural control and finds itself in deep opposition to the dominant discourses of radical Islamization.

With the influx of monetary aid provided by the Western world during and after the Afghan war, these two theatrical companies worked under the umbrella of NGOs and started producing plays according to the donor-funded issues that were in line with the neoliberalism movement globally. In the 1990s and 2000s, NGOs started development projects in Pakistan, during this time Ajoka and Tehreek e Niswan produced plays like Burqavaganza, Akhir Kyun(But Why), and Meri Zindagi ka Safar(A Journey of My Life) respectively. Burqavaganza was sponsored by British Council while Akhir Kyun and Meri Zindagi ka Safar were funded by British Department Fund for International Development administrated by British Council. Threek e Niswan aforementioned plays like Akhir Kyun (But Why) and Meri Zindagi ka Safar (The Journey of My Life) highlighted issues of forced marriages, honor killing, and mother-child health care. Akhir Kyun comprises various tales from reallife incidents of the heinous crime of honor killing. It unfolds that women, children, and men in rural Sindh where the feudal system is still dominant are persecuted at the hands of influential individuals and institutions like the police and local judiciary system known as Jirga.

Both these plays dealt with very pertinent social issues but the problem is that play like Meri Zindagi Ka Safar (The Journey of My Life) dealing with gynecological issues was presented in a Seminar on Women-child health in Karachi in 2010 in which the majority of the audiences were paramedics, hence it fails to reach to the communities who are victims of early marriage and poor reproductive health care. While plays like Akhir Kyun? (But Why?) that deal with a grave social issue but are donor-driven, hence deviates Tehreek e Niswan from its original ideology of a radical and political theatre. These NGOs commodify activist theatre and turn it into a source of income for donor agencies. The essence of theatre as an instrument of social critique and artistic expression is placed at the back burner, furthermore, it is the redeployment of western modernity as a way of economic development. Those donors fulfill their agenda of commodification while these theatre groups in return get recognition in Western metropolises. As Huma Ibrahim in her article Transnational Migrations says that literary productions in the subcontinent do not get recognition until and unless they are recognized in the "Western marketplace" (1998, p.34). Taking up local issues and portraying them from the Western lenses earn them a name in the literary arena hence the autonomous essence is 
marginalized as Arif Dirlik in his essay criticizes this commodification that the comprador intelligentsia of the third world is nurturing hence they find what Dirlik calls "an expression not so much of agony over identity, as it often appears, but of newfound power" (1994, p.339). This 'newfound power' is that writers like Azar Nafisi, Leila Ahmad, Nawal al Sidhawi, and Fatima Merssini became acclaimed Islamic feminists in the western world by providing a critique of Islam and women status in Islam which is in line with Western ideology.

Similarly, in Pakistan, this funded project of Ajoka initiated the debate that 'global intelligentsia' (1994, p.334) is promoting vistas of Western narrative about Islamic ideologies and practices especially after $9 / 11$ as Islamophobia emerged on the global fronts. Burqavaganza presenting Burqa(Veil) as a symbol of oppression and how women are forced to live in the four walls and not allowed to take decisions of their lives, hence it appears as a metaphor of ultra-conservative society. Though Ajoka is of the view that the purpose of using the veil as a symbol of hiding true selves in the play yet it sparked controversy since the veil has a religious connotation in Pakistani society. Ajoka and Tehrik e Niswan with time has transformed the ir ideology and content. Both these groups have now shifted their ideology to human rights activism, which carries the 'white man's burden of civilizing and voicing "the wrongs of the unfit." (2004, p.524) Spivak contested in her essay "Righting Wrongs" that "human rights culture" runs on unremitting Northern-ideological pressure, even when it is from the South; that there is a real epistemic discontinuity between the Southern human rights advocates and those whom they protect."(2004, p.527) Spivak suggests these NGOs and social activist organizations having an access to the Western global public sphere are the agents and takes up the responsibility of speaking on behalf of the disempowered and dispossessed.

Both these theatre groups were torch bearer of resistance against oppression and began their journey as a political theatre but lately, they have jumped on the bandwagon of what Spivak espouses as "native informants" (1999, p.ix) that are more eager for promoting Western perceptions through their plays hence transforming protest into paid activism. It is equally interesting to mention that with the shift in socio-cultural landscape in Pakistan since the dawn of the $21^{\text {st }}$ Century, the overt political oppression faced by these two theatre groups has become a thing of the past, and that theatre of social activism still very much continues in the face of capitalism and commodification.

\section{Examining Anglophone Drama and The atre in Pakistan}

English drama writing tradition in Pakistan has been a lackluster affair both in terms of creativity and literary criticism. Muneeza Shamsie in her latest work Hybrid Tapestries says "English Play by a Pakistani writer is still rare". (2017, p.517) as she presents a brief overview of the works of those playwrights who are of diasporic origin. English drama writing had not flourished in Pakistani culture for the reason pointed out by Zia Mohhyiuddin that drama flourish in those societies where theatre is part and parcel of cultural milieu $(2017$, p.515) as there is an example of India where drama as performing art is an essential part of Indian culture. For this said reason Indian playwrights are noteworthy and have received international acclaim. This has not been the case in Pakistani culture for two apparent reasons. First, drama as a performing art is seen in contradiction with Islamic values and traditions by religious extremist elements. Second, in Pakistan theatres are very rare in number, where drama can be performed. The notable contributions in Pakistani Anglophone drama are by the writers of diasporic origin, like Hanif Qureshi, Rukhsana Ahmad, Ayub Khan-Din, and Wajahat Ali. Major Themes and concerns of diasporic playwrights are identity issues of the Pakistani diaspora as they deal with the third space of enunciation.

Two modern-day theatre groups located in the Capital of Pakistan have made rounds in the performing arts of Pakistan one of them is Shah Sharabeel a, contemporary name on the canvas of Pakistani Anglophone theatre. He produced and directed plays like Moulin Rouge, Bombay Dreams, Phantom of the Opera under Centre Stage Production. Sharabeel's services to the theatre are noteworthy as he moved away from imitation and adaptation of Western plays in his theatrical productions but the intriguing and pertinent observations are that the performances and productions aren't very frequent and remain few and far between.

The other group is Theatre Wally (Theatre People) founded back in 2005 who selected issues of social welfare as their thematic concerns in theatrical performances. Their artistic director Fizza Hassan believes that "due to economic conditions and changing priorities, the cultural spaces are crippled which provide a medium to combat fear and divide. Not only that they are also effective in bringing people together and create tolerance in an environment of mutual understanding by creative 
and artistic expressions"10. Theatre Wally has produced plays in Urdu and English both and also presented translated Urdu version of waiting for Godot under the title Godot $k$ Intezar Mein. Their play Zard Patton Ka Bann was created in English under the title On Common Grounds was performed in 2017 in Oregon Shakespeare Festival and Artists Repertory Theatre in Portland. Both these theatre groups have amateur actors and performers hence created chances for the young people who are talented and are eager to perform in the theatre to prove their mettle in acting.

A significant point to mention here is that no indigenous or diasporic Pakistani English Playwright could win a place in the drama anthologies written and complied in Western academia. One such example is Postcolonial Plays: An Anthology, edited by Helen Gilbert. This anthology includes playwrights from Malaysia, West Indies, India, Singapore, and dramatists from many other former colonies, except Pakistan. The corpus available in the literary criticism of English drama writing in Pakistan, or South Asian drama is based on diasporic angst. Hence Pakistani English Drama writing is limited in creative fecundity and critical recognition. Having said that in recent years Usman Ali emerged as an indigenous creative dramatist in Pakistan since Usman Ali is currently residing in Pakistan and as a literary figure he observes these social and political circumstances of Pakistani society so his plays address these prevalent issues to develop insight and ignite a change in the mindsets of the people for better socio-political conditions. Ali's plays are thought-provoking interventions as theatre and drama hold the power of engagement more than any other literary and performing genre for mobilization and raising consciousness.

$\mathrm{He}$ received attention and popularity in the field of Pakistani English drama with the publication of The Guilt and The Last Metaphor (2014). Later on, Ali has shown his creative talent in three more plays, The Odyssey (2016), The Breath \& The Flute (2017). His works are deeply rooted in Pakistani culture and society. His characters are common people with ordinary social backgrounds. Edward Bond in his blurb of The Last Metaphor says that "Ali lives in a society where experience is immediate and direct" (45). This leads to the idea that Ali's plays are a reflection of the socio-psychic conditions of laymen residing in Pakistani.

Residing in District Mandibhauddin, Punjab Pakistan Usman Ali did his MPhil from Punjab University Lahore. Usman Ali's name echoed on the literary landscape of Pakistan with his dramatic script of Hamlet's Madness: Feigned or Real (2000) performed in the British Council's celebration of Shakespeare's Birthday at Lahore. It was directed by the late Madeeha Gohar who was a founding member of Ajoka Theatre ${ }^{11}$. Ali has to his credit the script of An Imagined Interview with Robert Frost (2001). However, his first published work is The Speaking Silence (2007) which is a translation of Gulzar's writings. Ali won Tofeeq Rafat Drama Prize in 2016 and later in 2018, he joined Iowa University for its prestigious and well-established International Writing Program that connects writers across the globe. Ali's plays will be performed at Royal Court Theatre in London in the coming years. He also established Ali's Theatre in Manddibhauddin which was once a sub-campus of the University of Sargodha where his plays were performed. This campus is recently closed by the Higher Education Commission of Pakistan on technical grounds and Ali's Theatre is no more active currently, though Usman Ali is trying to restore it. Staying back in indigenous land Usman Ali is writing Drama in English by indigenization local culture and traditions.

It is important to mention that Ali's Plays get critical reception from Western playwrights like Edward Bond and Elizabeth Kuti. Edward Bond has written blurbs for The Last Metaphor and The Odyssey. Bond argues that The Last Metaphor depicts Ali's ability to present direct and day-to-day experiences. Ali's plays are opening a window to local and indigenous raw experiences as Bond in his blurb of The Last Metaphor calls it a "direct experience in dramatic form." He further says that Usman Ali describes the human relationship in the best possible way. Bond in his blurb about The Odyssey appreciates Ali's creative genius, in bringing history to contemporary settings. The Odyssey not only depicts the violence prevailing in society, but also the "search of understanding and meaning" (Bond 43) in times of social turbulence and heartlessness. Ali's thematic concerns are deeply rooted in Pakistani society and culture. Ali's plays are not merely an aesthetic escape but a convergence of socio-political environment and everyday life of a common man residing in Pakistani society, hence

\footnotetext{
${ }^{10} \mathrm{https}: / / \mathrm{www}$. thenews.com.pk/print/273102-theatre-wallay-bring-original-play-in-town ${ }^{11}$ Founded in the times of dictatorship of General Zia ul Haq, Ajoka Theatre is considered the pioneer theatre of
resistance in Pakistan that took up social issues like women rights
} 
creating various thought-provoking intersections between literary productions and growing dissent of the intelligentsia in a developing country like Pakistan by employing performing strategies

Claire Chambers in her newspaper article "A Scene in Mandi Bahauddin" discusses her visit to Pakistan and her acquaintance with Ajoka Theater and Shahid Nadeem. Chambers saw Ali's The Last Metaphor as it was performed in Ali's Theater during a conference at Mandi Bahauddin. She compares Ali's Play with Shahid Nadeem's, whom she finds a radical playwright. She finds Ali as a disciple of Shahid Nadeem in drama writing, with the only difference that Ali is writing in English and Shahid Nadeem writes in indigenous languages like Urdu, Seraiki, and Punjabi. She further says that there are many commonalities between Ali's The Last Metaphor and Shahid Nadeem's The Dead Dog. She further discusses The Last Metaphor as a play that reflects horrors of violence. Chambers sees these young Pakistani dramatists as hope for keeping theatre alive in Pakistan.

\section{Conclusion}

After providing a detailed overview of Pakistan's socio-political conditions over the years, to conclude there are three main observations. Firstly, arts and literature depict and simultaneously engage people in any soc iety with the ir socio-political and cultural landscapes. Government has to play a vital role in the revival of performing arts as the growth and development of these is directly proportional to the conducive socio-political. Art cannot flourish in hostile and entertainment-starved environments. The future doesn't look very promising for theatre and drama as Pakistan's socio-political conditions are engulfed in oppression, restrictions and there is very little space for dialogue.

Secondly, intellectual or serious theatre remains a privilege of the few and has more commercial concerns rather than providing aesthetic and thought-provoking pinch. The theatre stage used to be a platform for great artistic expression, but its commodification leads to scripts losing substance and performers choosing money over matter. As a result, drama and theatre are only produced in metropolises like Islamabad, Lahore, and Karachi and even in these Metropolitan cities few active theatre and drama groups have created a sort of hegemony as Ajoka is dominant in Lahore and NAPA (National Academy of Performing Arts) is ruling in Karachi.

Lastly theatre and drama whether in Urdu or English is an engagement with the masses until and unless there is a proper representation of local themes and concerns, feasibility in productions and frequent performances the future of theatre and drama in Pakistan remains obscure and vague.

\section{References}

Ali, U. (2017). The Breath, The Flute. New Line.

---. (2014). The Guilt. Sawan.

---. (2014). The Last Metaphor. New Line.

---. (2016). The Odyssey. New Line.

Belsey.C.(2005) Textual Analysis as a Research Method.In G. Griffin (Ed). Research Methods for English Studies. (pp.157-174). Edinburgh: Edinburgh University Press.

Claire, C. (2017, December). A Scene in Mandi Bahauddin. The Dawn. https://www.dawn.com/ news/1374166

Curtis. L. (2016) Religious Freedom in Pakistan: Glimmers of Light on a Darkening Horizon. The Review of Faith and International Affairs, 14(2),20-30. https://www.tandfonline.com/doi/full/ 10.1080/15570274.2016.1184439

Dirlik, A. (1994, Winter). The Postcolonial Aura: Third World Criticism in the Age of Global Capitalism. Critical Inquiry, 20(2), 328-356.

Eugene, E. V. (1992). The Playful Revolution. Theatre and Liberation in Asia, Indianan University Press

Gilbert, H. (2001). Postcolonial Plays: An Anthology. New York.

Ibrahim, H. (1998, January). Transnational Migrations and the Debate of English Writing in/of Pakistan. Ariel. 29(1),33-48. https://journalhosting.ucalgary.ca/index.php/arie1/article/view/ 33929

Jalibi, J. (1989). Tareekh e Adab e Urdu. Educational Publishing House.

Jalal, A. (1991). The Convenience of Subservience. Women Islam and the State. ed. Deniz Kandiyoti. MacMillan Press.

Khan, F, A. (2005). The Critical Stage: The Role of Secular Alternative Theatre in Pakistan. Seagull.

Khoosat, S. S. (18 Jan 2020). Sarmad Khoosat Pens Open Letter to Imran Khan as People Try to Halt His Film's Release. The Dawn. Retrieved from https://images.dawn.com/news/1184463 
Moonis, A. (2015). The Dynamics of Elite Politics in Pakistan and Its Nexus with Clergy and Military. Journal of South Asian and Middle Eastern Studies,38(2),44-46. www.jstor.org/stable/10.33428/jsoutasiamiddeas.38.2.0044. Accessed 1 Apr. 2020.

Mundrawala, A.(2009) Shifting Terrains: The Depoliticisation Of Political Theatre In Pakistan. (Published Thesis, University of Sussex, Doctoral).The University of Sussex. http://sro.sussex.ac.uk/.

Peyma, N. D. (2009). Postcolonial Drama: A Comparative Study of Wole Soyinka, Derek Walcott and Girish Karnad. Rawat Publications.

Qureshi, M, A. (1989), Dramay Ka Tarikhi Wa Tanqidi Pas-i-Manzar. Sang e Meel.

Rehmani, E. (1987). Agha Hashar K Dramay. Majlis e Taraki e Adab,1987.

Shaheed, F. (2008, December). Gender Religion and the Quest for Justice in Pakistan (Draft). United Nations Research Institute of Social Development, Religion, Politics and Gender Equality. 146.http://users.ox.ac.uk/ qehwemc/documents/WEBPakistandrft.pdf

Tahir, F. (2019, April). What Drives Religious Intolerance in Pakistan. The Daily Times. https://dailytimes.com.pk/375790/what-drives-religious-intolerance-in-pakistan/

Shamsie, M. (2017).Hybrid Tapestries.Oxford University Press.

Spivak, G, C. (1999). A Critique of Postcolonial Reason: Toward a History of the Vanishing Present. Cambridge, 1999.

Spivak, G, C. (2004, Summer). Righting Wrongs. The South Atlantic Quarterly. 103(2/3). 523-581.

Wa Thiong'o, (1986). Decolonizing the Mind: The Politics of Language in African Literature. Heineman, 1986.

Worthen, W. B. (2002) The Harcourt Anthology of Drama: Brief Edition. Harcourt College Publishers.

Zakes, M. (1995, February). The Role of Culture in the Process of Reconciliation in South Africa. (Paper presentation). The Centre for the Study of V iolence and Reconciliation, Johannesburg. SA. 